\title{
CHANGING PERSPECTIVES ON RESPONSIBLE HERITAGE SITE MANAGEMENT: THE CASE OF LUXOR CITY, EGYPT
}

\section{Perspectivas em mudança sobre a gestão responsável de sítios de patrimônio: o caso da Cidade de Luxor, Egito}

\author{
Eman Shokry Hesham* \\ Inken Baller ${ }^{* *}$
}

\begin{abstract}
This paper aims to enhance critical awareness about the development of heritage site management, specifically focusing on archaeological sites and their adjacent communities in Egypt. To what extent does heritage site management assume responsibility for local communities? For their identity? And for tourism practices? This paper uses the heritage impact assessment tool developed by ICOMOS to assess the management systems and the heritage influence of the UNESCO World Heritage Site "Ancient Thebes with its Necropolis" on the modern-day city of Luxor, Egypt. This tool proposes a set of recommendations for local and national authorities to develop action plans that safeguard the living history of the area around the site. The results suggest ways in which the tool could be improved by enhancing mitigation strategies for tourism-related impacts and re-identifying the variables of Egyptian archaeological sites in order to develop more responsible models of local community identity and visitor awareness.
\end{abstract}

Keywords: heritage management plans; heritage impact assessment; World Heritage Site; mitigation strategies; Luxor City

\footnotetext{
* Doctoral student. Brandenburg University of Technology (BTU).

E-mail: heshaema@b-tu.de

** Architect. Professor at Brandenburg University of Technology (BTU).
} 


\section{RÉSUMÉ}

Ce texte a pour objectif de stimuler une conscientisation critique au sujet du développement du management de sites patrimoniaux, notamment dans le cas de sites archéologiques et de leurs communautés avoisinantes en Égypte. Jusqu'où le management de sites patrimoniaux agit-il de manière responsable vis-à-vis des communautés locales ? Pour leur identité ? Et par rapport au tourisme ? Ce texte se sert de l'outil d'évaluation d'impact du patrimoine développé par ICOMOS pour analyser les systèmes de gestion et l'influence du patrimoine du site du patrimoine mondial de l'UNESCO «la Thèbes antique et sa nécropole »sur la ville moderne de Louxor, en Égypte. Cet outil propose aux autorités locales et nationales un ensemble de recommandations visant à développer des plans d'action pour sauvegarder l'histoire vivante dans l'aire située autour du site. Les résultats de l'analyse suggèrent des manières d'améliorer l'outil en augmentant les stratégies d'atténuation des impacts liés au tourisme ainsi qu'en redéfinissant les variables des sites archéologiques égyptiens de manière à développer des modèles plus responsables en ce qui concerne l'identité des communautés locales et la conscientisation des visiteurs.

Mots-clés: plans de gestion du patrimoine; évaluation de l'impact du patrimoine; site du patrimoine mondial; stratégies d'atténuation; ville de Louxor

\section{RESUMO}

Este texto tem como objetivo estimular uma conscientização crítica em relação ao desenvolvimento da gestão de sítios patrimoniais, especialmente no caso de sítios arqueológicos e das comunidades vizinhas no Egito. Até onde a gestão de sítios patrimoniais age de forma responsável em relação as comunidades locais? Para a identidade destas comunidades? E para os turistas? Este texto usa a ferramenta de avaliação do impacto do patrimônio desenvolvido por ICOMOS, para analisar os sistemas de gestão e a influencia do sítio do patrimônio mundial da UNESCO "Tebas antiga e sua necrópole" sobre a cidade moderna de Luxor, no Egito. Esta ferramenta propõe às autoridades locais como nacionais um conjunto de recomendações destinadas a desenvolver planos de ação para salvar a historia viva localizada ao redor do sitio. Os resultados da análise sugerem meios de melhorar esta ferramenta aumentando as estratégias de mitigação dos impactos ligados ao turismo assim como definindo de novo as variáveis dos sítios arqueológicos egípcios de modo a desenvolver modelos mais responsáveis com respeito à identidade das comunidades locais e a conscientização dos visitantes.

Palavras-chave: planos de gestão do patrimônio; avaliação do impacto do patrimônio; sitio do patrimônio mundial; estratégias de mitigação; cidade de Luxor 


\section{Introduction}

The excavation of the accumulated mud that buried the ruins of Luxor Temple began in 1881. Several years later, foreign commissions for the excavation and study of the archaeological sites at Karnak and Luxor Temple were created. The subsequent influx of British tourists to the region began to change the nature of the villages surrounding the Luxor and Karnak Temples and mud houses built on the ruins were demolished. In 1886, the company Thomas Cook \& Son inaugurated a line of Nile steamers travelling from Cairo to Aswan. In order to make the newly created town of Luxor suitable for European tourists, Thomas Cook \& Son established some public services and urban improvement projects, restoring existing amenities and providing more for tourists. Since then, the city of Luxor (Figure 1) has faced social and economic challenges and has depended on tourism for its economic prosperity and public services. It has also relied on the foreign excavation missions to ensure the preservation of the archaeological sites and monuments.

Despite the importance of its heritage properties, the government of Egypt does not systematically integrate heritage impact assessment (HIA) tools in its planning process. This paper will examine the ongoing project titled the Comprehensive Development for the City of Luxor as a case study to which to apply a HIA. The focus area will be the east bank of Luxor City, which forms part of the World Heritage Site (WHS) "Ancient Thebes with its Necropolis," listed as a UNESCO Heritage site in 1979. The HIA used here is the "Guidance on Heritage Impact Assessments for the Cultural Heritage Properties," developed by the International Council on Monuments and Sites (commonly known as ICOMOS) in 2011 (ICOMOS 2011). 
Figure 1 The Location of the Heritage Sites and the Expansion of Official Urban

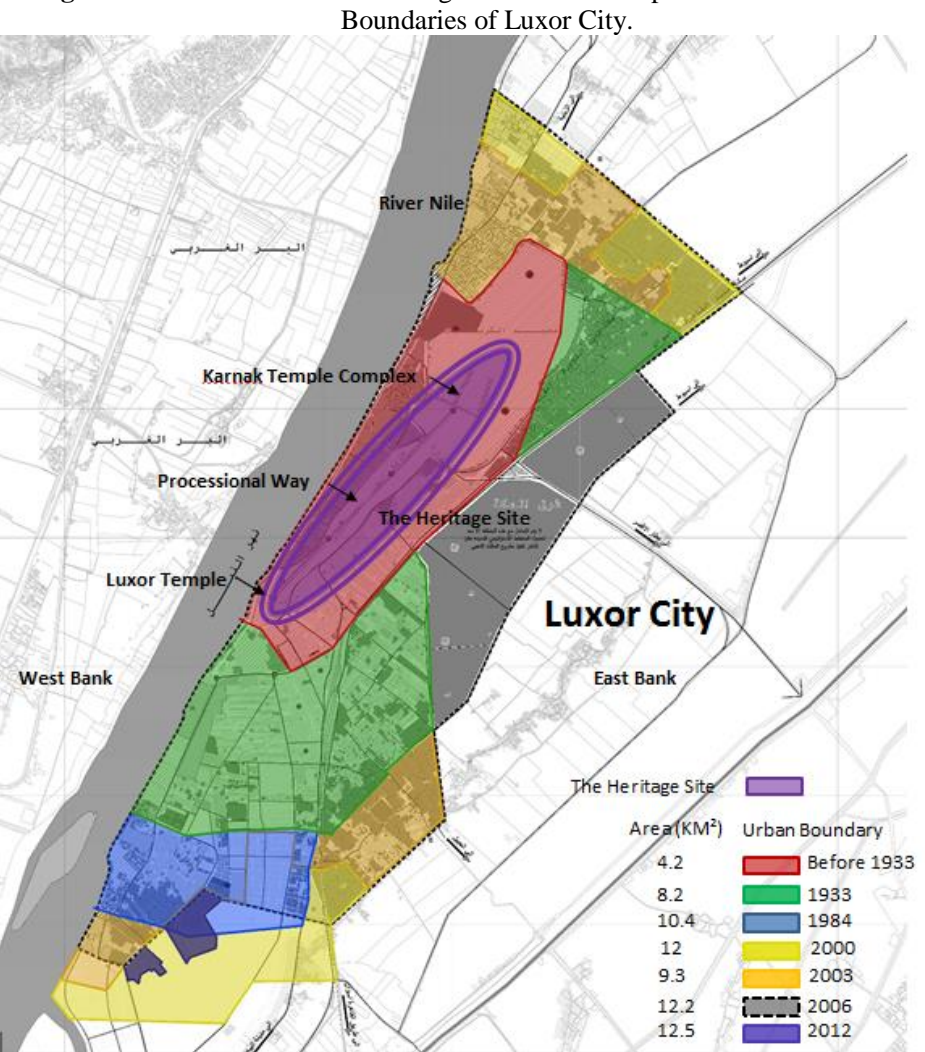

Adapted by the author from WALMUJTAMA'ĀT AL'UMRANIYA 2015; GENERAL ORGANIZATION FOR PHYSICAL PLANNING 2005. 


\section{Luxor City, an overview}

The UNESCO World Heritage Site "Ancient Thebes with its Necropolis," one of six UNESCO-listed sites in Egypt, is located in the modern city of Luxor. This paper concerns a part of the WHS which is located on the east bank of the River Nile in Luxor City, Luxor Governorate. It contains Luxor Temple, the Karnak complex, and the avenue that connects them. The WHS covers an area of approximately $12.5 \mathrm{~km}^{2}$, including the buffer zone in the east bank, and the modern-day population within that area is approximately 210,936 inhabitants (LUXOR GOVERNATE, 2017).

At the moment, Luxor City is a group of small villages built over the ruins of Luxor Temple, parts of the Karnak Temple complex and the sphinx-lined avenue. The main mosque, Abu el-Haggag, was built over the courtyard of Luxor Temple in the $13^{\text {th }}$ century and is part of the contemporary city. It "represents a tradition of continuous worship at Luxor Temple for almost thirty-five centuries" (The Oriental Institute, 2014). The annual religious festival in Luxor, which celebrates the birth of Sheikh Yousuf Abu el-Haggag, represents the continuity of the ancient Egyptian festival of Opet, during which boats are paraded around Luxor Temple (for more about the Opet festival, see Wickett 2009).

\subsection{Luxor City before the 19th century}

A hill of some 15 metres, gradually built up from accumulated mud and rubbish, lay around and over the Luxor Temple area. Upon that, a small village had been built. Described "as not in a prosperous condition" (BUDGE, 1925: 384), the village of Luxor consisted of houses, huts, barracks, pigeon towers, and stables (SCIENCE, 1885:371) and the houses of "the English, American and Prussian consuls, each with its flagstaff and ensign" (EDWARDS, 1876:122), who were generally native Egyptians.

The clearance of the sites of Luxor and Karnak was begun in the early 1880s by Gaston Maspero (1885), and the inhabitants were compensated with money and land elsewhere. Excavations started in 1884-1885. 


\subsection{The development of heritage site management}

The analysis of the heritage site management of the monuments, the local community, and visiting tourists are discussed in order to better understand the impact of management systems and strategies, not only on the heritage site, but also on the local community, from the $19^{\text {th }}$ century to the present time.

\subsubsection{Heritage site management and antiquities}

The temples have been frequented by European tourists since the $19^{\text {th }}$ century. At that time, the Rosetta Stone was decoded, and the pioneering Egyptologists Jean-François Champollion and Karl Richard Lepsius began to record and publish their work (SULLIVAN, 2008). This attracted even more visitors to explore ancient Egypt.

In the first part of the $20^{\text {th }}$ century, the first formal commission for the study and conservation of Karnak Temple was created. In the mid- $20^{\text {th }}$ century, the Egyptian Antiquities Service cleared part of the Processional Avenue (SULLIVAN, 2008). The Ministry of State for Antiquities is in charge of excavations to this day. Many international projects and missions were created, and current research includes studies on bas-reliefs; surveys in Luxor, such as the Centre franco-égyptien d'étude des temples de Karnak; the Karnak Hypostyle Hall Project; the Chicago Medieval Luxor Project; and University of Chicago's Epigraphic Survey. ${ }^{1}$

Recent excavations in the area south of Karnak revealed structures containing industrial activities dating from the Roman and medieval periods (BORAIK, 2010: 49). Some other structures that were found during excavation were defined as settlements, which are rarely the focus of research excavations. For example, excavations revealed that the Temple of Akhenaten in Karnak was built on top of the remains of domestic structures dated to the Middle Kingdom (MILLET and MASSON, 2011). Other residential structures were

1 A list of different missions, projects, and institutions at Karnak Temple is mentioned by Sullivan in her publication Digital Karnak: Introduction to the Temple of Karnak (2008). Boraik, in his report Sphinx Avenue Excavations: First Report (2010), focused on the history of the excavations in the Processional Avenue area and Luxor Temple. 
found in the area of Karnak dating to later periods, most of which were built with mud-brick. ${ }^{2}$ These structures prove that the ancient areas on and around the Luxor and Karnak temples included not only religious sites, but also domestic and industrial sites.

One of the annual reports of the Chicago Medieval Luxor Project, published in 1986, commented on the excavation work of the early $19^{\text {th }}$ century. It stated that "from 1881 until 1960, Luxor temple and processional way were cleared, which caused the destruction of the centre of the (current) city of Luxor, a mound of some 15 meters of archaeological evidence for the history of Luxor after the Pharaohs" (WHITCOMB and JOHNSON, 1986:31). The authors believe there is one area that still preserves some evidence of the ancient town, located along the Nile River near the pylons of Luxor Temple.

\subsubsection{Heritage site management and the community}

After the late $19^{\text {th }}$ and early $20^{\text {th }}$ centuries, when the inhabitants within Luxor Temple were expropriated, amenities for tourists were established within a few years. These included a post office, a bank, a telegraph office, tennis courts, sporting clubs, and "many other necessaries for civilized life" (HUMPHREYS, 2011). Not only services for tourists, but also services for locals were considered. As proudly mentioned by Sir Budge in his 1925 Cook's Handbook for Egypt and the Egyptian Sudan, "quite early in the history of the modern development of Luxor, Mr. Cook founded a hospital, and hundreds of the sick and suffering gladly and promptly availed themselves of the medical assistance which he provided gratis. [...] The road along the river front was widened, and the quay built, and some other urban improvements" (BUDGE, 1925:385).

With the success of the Nile cruises, European wares began to fill the bazaars. The Sacred Lake in Karnak, a source of disease for

2 The article "Karnak: Settlements," by Millet and Masson (2011) is an excellent review of the excavations of the domestic structures found in Karnak from as early as the 18th Dynasty until the Third Intermediate Period. Millet and Masson claim that the research on the region around Thebes is insufficient and that the character of the town is far from understood. They argue for the necessity for further archaeological investigations. 
locals, was infilled. In the following years, the local community also improved the town, including better homes and a new mosque. In 1921, the mosque's benefactors also built residences for poor and elderly members of the community (BUDGE 1925, 386). Thomas Cook's son John Mason Cook upgraded the river bank and encouraged local authorities to clean the streets and enhance road conditions. Budge (1925: 385) claims that Cook was called the "friend of the poor" and the "father of Luxor."

\subsubsection{Heritage site management and tourism}

Herodotus and Strabo claimed to have visited Thebes - the ancient name for the location of modern Luxor-and its "great number of temples" (SULLIVAN, 2008). However in later centuries, the importance and the meaning of Thebes and its temples seems to have been lost, until European visitors rediscovered Thebes. In 1799, Napoleon Bonaparte sponsored a scholarly mission to Egypt (SULLIVAN, 2008: 16) in order to catalogue the monuments of ancient and modern Egypt. The mission's work was published in a series of volumes titled Description de l'Égypte (Bednarski, 2005).

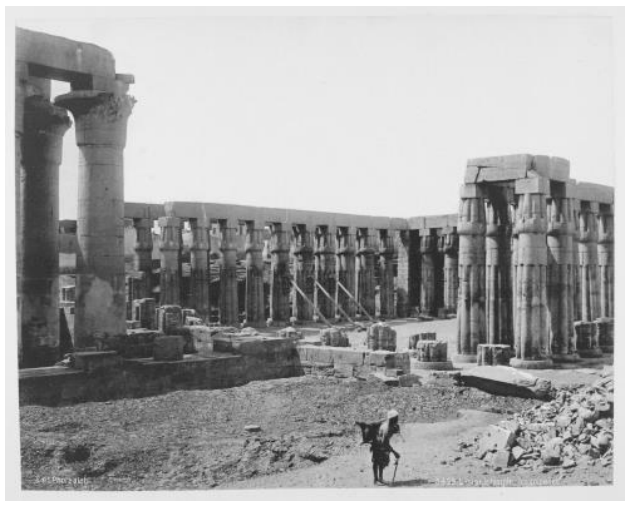

Figure 2 Main court yard of Luxor Temple, unknown date, probably 1870 s.

Source: General Research Division, The New York Public Library. http://digitalcollections .nypl.org/items/ 510d47d9-4a72-a3d9e040-e00a18064a99 
Figure 3 Luxor Temple and Brasserie Rohrmoser in 1909.

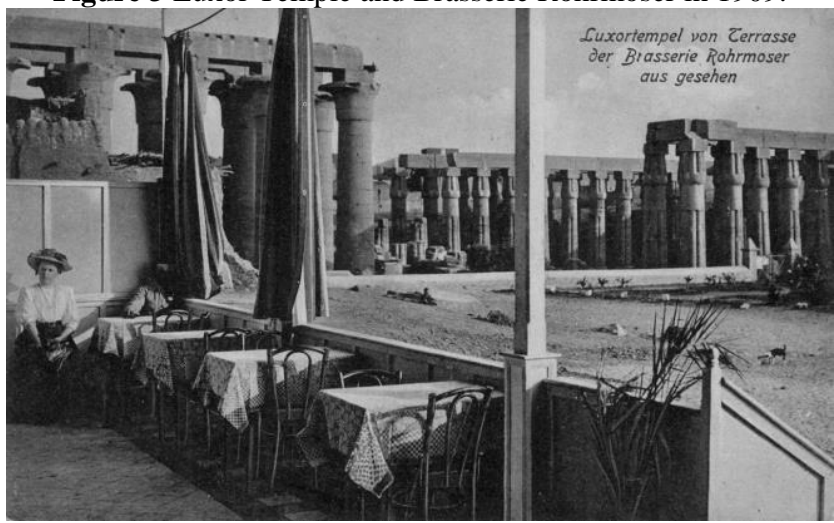

Source: http://www.louxoregypte.fr (Accessed 15.11.2016)

Photo courtesy Max Karkégi. http://www.egyptedantan.com/

The reputation of Luxor grew, both for its remarkable attraction and for its moderate climate in winter. Figures 2 and 3 shows the area in front of the courtyard in Luxor shortly after the expropriation of the villagers. A café for tourists (Figure 3) was built with a view of the whole temple. To keep up with the growing number of visitors, John M. Cook, whom Budge called "the great organizer of the tourist traffic," first enlarged and later rebuilt the old Luxor Hotel, now Egypt's oldest surviving hotel. He also built Karnak Hotel, the Grand Hotel, and the Savoy Hotel (HUMPRHEYS, 2015).

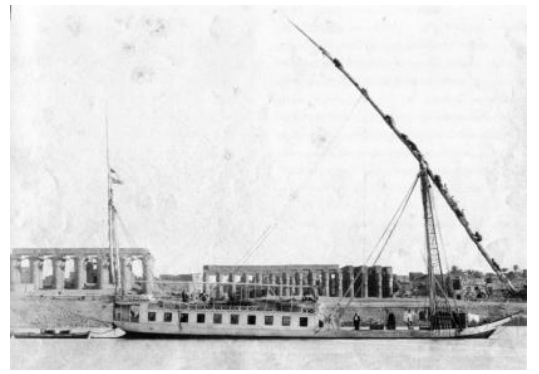

Figure 4 Dahabiya at Luxor in 1880 .

Source: FERRI, 2008. 
Dahabiya houseboats were the early means of travelling on the Nile from Cairo to Aswan, and Luxor was the ideal spot to stay en route. In 1886, Thomas Cook \& Son introduced a new line of steamers, capable of transporting more people between Cairo and Aswan. This appealed to a wider clientele (SAAD, 2000; Humphreys, 2011). The dahabiya were still used for slow travellers who sought luxury and style, and who also complained occasionally about the enormous flow of tourists, calling them "Cookis" and "Cookesses" (HUMPHREYS, 2011).

Lessons learnt from observing and studying the development of heritage site management at Luxor

The renowned heritage of Luxor enjoyed international prominence, changing the nature of the local community in terms of its social networks, economic income, and urban infrastructure. Archaeological excavations and new means of transportation greatly influenced the flow of visitors. The public services of the small, rural town were adjusted accordingly to accommodate European tourists. These transformations had positive impacts on the local community because they improved living conditions and led to the creation of hospitals, public gardens, and waste management services, while also providing revenue from tourism. The new interest in ancient Egyptian monuments led to the demolition of many residential structures in the heart of the town. Archaeological excavations up to the first half of the $20^{\text {th }}$ century focused on exposing the ancient remains of the site and disregarded the domestic structures of the medieval period. These medieval structures may have contributed to the site being considered by UNESCO Criterion V as an "outstanding example of a traditional human settlement and land-use" (THE CRITERIA FOR SELECTION, UNESCO 2016). 


\section{Using the Heritage Impact Assessment tool}

In the light of the history of the city and the early management strategies that were undertaken to make Luxor suitable for tourists, the first master plans for the city, created in 1984 and 1993 did not address the problem of increasing urban encroachment on both arable land and the heritage site. Figure 1 indicates the continuous encroachment on arable land, which covers all the east bank of the Nile River outside the current official WHS boundaries. The ICOMOS HIA will be used to evaluate the latest update of the development plan in 2015.

\section{Brief description of the Comprehensive Development Plan for the City of Luxor}

The Comprehensive Development Plan for the City of Luxor (CDCL) is the latest development plan adopted by the Egyptian government. It includes development activities for the eastern and western banks of the Nile river at Luxor. The CDCL was first launched in 1996, in a partnership of the Ministry of Foreign Affairs of Egypt; the Ministry of Housing, Utilities and Urban Development; the Higher Council of Luxor City; and the United Nations Development Programme (UNDP, Egyptian office). The CDCL was undertaken by the Ministry of Housing, Utilities and Urban Communities and the former Higher Council of Luxor City, now called the Governorate of Luxor (YOUSRY, 2004:2).

The CDCL is generally intended to preserve and enhance Luxor City's old neighbourhoods and traditional market areas, and to redevelop some government properties and underutilized private properties in order to create sites within the open-air museum at Karnak Temple and heritage district (ABT ASSOCIATES INC. \& BARAKA TRADING, 1998). The goal is to create new commercial developments and tourism support services, as well as increase open public spaces. The CDCL required demolishing a large residential and commercial area in the heart of Luxor, in order to expose the Processional Avenue and thereby re-connect Luxor and Karnak. The demolition has resulted in the relocation of public and private 
residential and commercial properties, such as houses, bazaars, schools, and gardens. Proposed new developments are to be compatible with tourism; these include hotels, an IMAX cinema, and other city facilities. These new developments have not yet been implemented.

One of the CDCL projects, the Excavation and Restoration of the Avenue of the Sphinx, requires the clearance of the processional way. However, following the project's suspension due to lack of funds and political support, the site now suffers from to neglect and garbage accumulation.

According to the May $2015^{3}$ report prepared by the World Heritage Committee in Bonn, Germany, the committee requested that Egypt provide a heritage impact assessment for the ongoing projects, in particular those related to infrastructure development.

\title{
Heritage impact assessments
}

As previously mentioned, a HIA is used in this study to evaluate whether the CDCL meets the requirements of ICOMOS and UNESCO. One of the definitions of HIA is as follows:

\begin{abstract}
"A process of identifying, predicting, evaluating and communicating the probable effects of a current or proposed development policy or action on the cultural life, institutions and resources of communities; Then integrating the findings and conclusions into the planning and decision making process, with a view to mitigating adverse impacts and enhancing positive outcomes" (SAGNIA, 2004).
\end{abstract}

HIA is also used "to evaluate effectively the impact of potential development on the Outstanding Universal Value of [heritage] properties" or OUV. ICOMOS defines OUV as qualities that contribute to the inscription criteria and the authenticity and 
integrity of the site (ICOMOS, 2011). In 2012, the International Association for Impact Assessments (IAIA) compiled a key citation series for what it considered as the core literature for cultural impact assessments (Fleming and Jesus 2014), among which is the Guidance on Heritage Impact Assessments for Cultural World Heritage Properties (ICOMOS, 2011). IAIA publishes the annual online journal Impact Assessment and Project Appraisal, which focuses on different impact assessment tools and methods. Partal and Dunphy (2016) published a systematic literature review of current methods and practices of cultural impact assessments around the world.

\section{The significance of the heritage site at Luxor}

The starting point of a HIA is to define the cultural resource, its significance, and its attributes. The World Heritage Site "Ancient Thebes with Its Necropolis" was listed in 1979 under criteria I, III, and $\mathrm{VI}^{4}$. At the moment, there is no published statement of outstanding universal value for the site. This is problematic as the OUV are used in preparing the HIA in order to assess the management of the WHS. The selection criteria represent the attributes that need protection. Criterion I is "to represent a masterpiece of human creative genius," in this case the Luxor and Karnak Temples and the processional way that create the historic landscape. Criterion III is "to bear a unique or at least exceptional testimony to a cultural tradition or to a civilization which is living or which has disappeared." Criterion VI is "to be directly or tangibly associated with events or living traditions, with ideas, or with beliefs, with artistic and literary works of outstanding universal significance." This criterion is expressed in the exquisite craftsmanship of the construction and decoration of the temples and tombs of Luxor on both the east and west banks (UNESCO World Heritage Centre, 2017). Beside these internationally recognized values or attributes, a socio-cultural layer should also be considered. The ancient festival of Opet as currently represented by the festival Mulid Abu el-Haggag is 
celebrated by the local inhabitants and is a valuable intangible asset of the site.

\subsection{Assessment Methodology}

In addition to the ICOMOS Guidance on Heritage Impact Assessments for Cultural World Heritage Properties (2011), this current paper also integrates the "Framework Cultural Impact Assessment" by Sagnia (2004).

\section{Scope of Assessment}

This assessment reviews the development of the site management and tries to utilize lessons learnt from the impact of different developments on the local community, visitors, and heritage sites to develop mitigation strategies and actions that help protect the OUV. The HIA conducted here considers two development projects located in the study area in Luxor's east bank: "Creation of an open museum and heritage district", and "Excavation and restoration of the Avenue of the Sphinxes" (ABT ASSOCIATES INC. \& BARAKA TRADING, 1998; Yousry, 2004:26). ${ }^{5}$ The results are summarized below, and mitigation measures are then proposed.

\subsection{Threats to Luxor City}

\subsubsection{Socio-cultural and economic threats to the community}

There has been no real contribution to the creation of new job opportunities. According to the 2010 statistics, unemployment in Luxor Governorate is at $31.96 \%$. There has also been no concrete improvement to infrastructure, facilities, and housing plans in existing rural or urban areas in Luxor, as the focus has been to clear the centre

5 These are two of the six investment projects to support the implementation of both the master plan and the heritage plan of the CDCL (ABT ASSOCIATES INC. \& BARAKA TRADING, 1998) The other projects are: Creation of a new residential area (New Luxor City), Development of a tourist zone on El Toad Plateau, and Infrastructure provision for El Toad and New Luxor City, and Development of high-value agriculture and agro-processing industries. These projects were not taken into consideration in this paper as they are not as in proximity to the study area. 
of the city to provide more activities for tourism (CENTRAL AGENCY FOR PUBLIC MOBILIZATION AND STATISTICS, 2010). Moreover, small- and medium-scale enterprises have not been involved or encouraged in the new investment projects (YOUSRY, 2004:33).

\subsubsection{Threats to existing housing and local economic activities}

Demolishing parts of Luxor City, especially parts of the Processional Avenue, which is owned by the local community, isolates members of the local community from their social and economic networks. Clearing the processional way highlights the ancient path between Luxor and Karnak, but at the same time it erases interesting aspects of the medieval city.

\subsubsection{Management threats}

There has been no commitment of financial resources from the international, public, or private sectors for the implementation of projects (YOUSRY, 2004: 35). Furthermore, there is been no management body to monitor project performance and its long-term impacts, perhaps due to the lack of institutional capacity of Luxor Governorate (YOUSRY, 2004: 35).

\subsubsection{Vibration and Pollution from New Road Networks}

The development of new roads will increase the number of vehicles - primarily for transporting tourists - in the proximity of the heritage site, which will cause vibrations, which represent a dangerous threat to the ancient structures. The higher traffic volumes will also result in increased air, noise, and visual pollution.

\subsection{Classification of Potential Impacts}

The classification of potential impacts is grouped according to the nature of that changes that affect the values of Luxor, into physical, socio-cultural, economic, and environmental impacts. 


\subsubsection{Physical Impacts}

- Uncontrolled development in the buffer zone of the World Heritage Site (World Heritage Committee, 2015: 84). These include encroachment on arable land.

- Loss of qualities that contribute to the inscription criteria and the authenticity and integrity of the site, also termed loss of outstanding universal value (OUV) attributes. These include new infrastructure and underground constructions, such as water, gas, and sanitation that will affect the sites.

- Deterioration of walls and other constructions due to new building works. A combination of high vibration and humidity, a consequence of the new large-scale development projects, will potentially cause the deterioration of stone, mud, mortar, and paintings.

- Alteration to the historic fabric and appearance of the sites. Implementation of the new projects will lead to the destruction of significant heritage attributes.

- Negative impacts to the visual integrity of the urban context of the site. Due to the changing nature and fabric of the city, the land use changes from mainly residential, agricultural, and commercial to tourism and commercial.

- Isolation of a heritage attribute from its surrounding environment. The demolition of the residential district in favour of large-scale new developments will impact the authenticity of the site and will be out of context.

- The use of modern architecture. This architecture does not respect the context, and it affects the authenticity and integrity of the site. The proposed projects consider any new design's proportions, forms, colours, and materials.

\subsubsection{Socio-Cultural Impacts}

- Loss of community connection with cultural property. The new developments and their related services may lead to a loss of access to the plaza in front of the Abu el-Haggag mosque, the location of the annual festival of Mulid. 
- Changes in lifestyle. New development projects will provide facilities that serve the needs of tourists and businesses, and do not consider the community's skills, values, and needs. For example, there is no support for the main economic source of the local populations at the site, such as agricultural activities, bazaars, and related tourist handicrafts.

\subsubsection{Economic Impact}

- Decreased economic benefits to the local community. The projects proposed are heavily influenced by real estate developers; thus they decrease the economic benefits for those who rely on traditional activities, such as bazaars.

\subsubsection{Environmental Impacts}

- Different new establishments offer the basis and infrastructure for development associated with modern life; however, these can also have residual and cumulative impacts on the environment. These include the deterioration of nature, noise and increased carbon dioxide emissions. 


\subsection{Magnitude of Each Impact}

Table 1 Threat and Impact Matrix of New Developments on the World Heritage Site in Luxor City ${ }^{6}$

\begin{tabular}{|l|l|l|l|l|}
\hline & $\begin{array}{l}\text { Socio- } \\
\text { Cultural and } \\
\text { Economic } \\
\text { Threats to the } \\
\text { Community }\end{array}$ & $\begin{array}{l}\text { Threats to } \\
\text { Existing } \\
\text { Housing and } \\
\text { Local } \\
\text { Economic } \\
\text { Activity }\end{array}$ & $\begin{array}{l}\text { Management } \\
\text { Threats }\end{array}$ & $\begin{array}{l}\text { Vibration and } \\
\text { Pollution } \\
\text { from New } \\
\text { Road } \\
\text { Networks }\end{array}$ \\
\hline Physical Impacts & ++ & + & ++ \\
\hline $\begin{array}{l}\text { Uncontrolled } \\
\text { development } \\
\text { in the buffer } \\
\text { zone of WHS }\end{array}$ & + & - & ++ & + \\
\hline $\begin{array}{l}\text { Loss of OUV } \\
\text { attributes }\end{array}$ & - & - & ++ & ++ \\
\hline $\begin{array}{l}\text { Deterioration } \\
\text { of walls and } \\
\text { other } \\
\text { constructions }\end{array}$ & - & 0 & ++ & ++ \\
\hline $\begin{array}{l}\text { Alterations to } \\
\text { the historical } \\
\text { site }\end{array}$ & + & ++ & ++ & ++ \\
\hline $\begin{array}{l}\text { Loss of visual } \\
\text { integrity }\end{array}$ & - & ++ & + & + \\
\hline $\begin{array}{l}\text { Isolation from } \\
\text { surrounding } \\
\text { environment }\end{array}$ & + & ++ & + & \\
\hline $\begin{array}{l}\text { Conflict } \\
\text { between } \\
\text { modern } \\
\text { architecture } \\
\text { and WHS }\end{array}$ & 0 & + & & \\
\hline
\end{tabular}

6 This Threat and Impact Matrix is based on the matrix developed by Prof. Michael Schmidt and Prof. Britta Rudolff, for the class Heritage Impact Assessment at Brandenburg University of Technology, Cottbus-Senftenberg in the light of the ICOMOS guidelines (ICOMOS, 2011). 


\begin{tabular}{|c|c|c|c|c|}
\hline & $\begin{array}{l}\text { Socio- } \\
\text { Cultural and } \\
\text { Economic } \\
\text { Threats to the } \\
\text { Community }\end{array}$ & $\begin{array}{l}\text { Threats to } \\
\text { Existing } \\
\text { Housing and } \\
\text { Local } \\
\text { Economic } \\
\text { Activity }\end{array}$ & $\begin{array}{l}\text { Management } \\
\text { Threats }\end{array}$ & $\begin{array}{l}\text { Vibration and } \\
\text { Pollution } \\
\text { from New } \\
\text { Road } \\
\text { Networks }\end{array}$ \\
\hline \multicolumn{5}{|c|}{ Socio-Cultural Impacts } \\
\hline $\begin{array}{l}\text { Loss of } \\
\text { authenticity }\end{array}$ & + & ++ & + & ++ \\
\hline $\begin{array}{l}\text { Change to life } \\
\text { style }\end{array}$ & + & ++ & + & + \\
\hline $\begin{array}{l}\text { Uncontrolled } \\
\text { urbanization }\end{array}$ & - & ++ & + & + \\
\hline $\begin{array}{l}\text { Loss of } \\
\text { community } \\
\text { connection } \\
\text { with cultural } \\
\text { property }\end{array}$ & ++ & ++ & + & ++ \\
\hline Modernization & - & ++ & + & + \\
\hline \multicolumn{5}{|c|}{ Environmental Impacts } \\
\hline $\begin{array}{l}\text { Natural } \\
\text { deterioration }\end{array}$ & 0 & - & + & + \\
\hline Noise & 0 & 0 & + & ++ \\
\hline $\begin{array}{l}\text { Increased } \mathrm{CO}_{2} \\
\text { emissions }\end{array}$ & 0 & $?$ & - & ++ \\
\hline \multicolumn{5}{|c|}{ Economic Impact } \\
\hline $\begin{array}{l}\text { Decreased } \\
\text { economic } \\
\text { benefits to } \\
\text { local } \\
\text { community }\end{array}$ & ++ & ++ & ++ & - \\
\hline \multicolumn{5}{|c|}{$\begin{array}{l}\text { Impact not expected or predicted }(0) \\
\text { Impact likely to occur but also likely to be insignificant }(-) \\
\text { Impact likely to be significant }(+) \\
\text { Impact likely to be highly significant, with the potential to represent major damage to } \\
\text { the cultural heritage resource }(++) \\
\text { Impact requires further study (?) }\end{array}$} \\
\hline
\end{tabular}




\subsection{Mitigation Strategies and Actions}

The proposed mitigation measures and actions discussed in the following paragraphs take into consideration lessons learnt from the development of heritage management discussed in the first part of this paper.

\section{Strategy 1: Redefine "cultural" property and its values}

Action 1: Engage local communities in the decision-making process and empower them to enhance their living conditions. Offering tax incentives for controlled renovations to their properties is a practical example, especially for middle- and low-income communities.

Action 2: Avoid gentrification by minimizing demolition and by providing new housing for local populations, giving them equivalent or improved housing.

Action 3: Provide job opportunities for local communities in new projects.

Action 4: Support and promote the traditional local festival of Luxor, the Mulid Abu el-Haggag.

Action 5: Find realistic ways to reopen the Luxor Hotel, the oldest surviving hotel in Egypt. ${ }^{7}$

\section{Strategy 2: Develop a site management plan}

The site management plan, which still does not exist, ${ }^{8}$ should include guidance for development projects, operating instructions, and a means to identify adequate conservation actions and monitoring techniques. It should also involve local stakeholders, including community members and small and medium-sized businesses.

Action 1: Identify and fund appropriate conservation and protection techniques. These include techniques that avoid vibrations

7 The Luxor Hotel has stopped operating for more than 20 years because of a dispute between the Awqaf (religious endowments) and Investment ministries in Egypt, which caused a waste of public money. There were plans to reopen the hotel, according to the CDCL, but these never came to fruition (GOUD, 2008).

8 There is no management plan for this World Heritage Site, according to the last WHC Decision, 39 COM 7B.49, in 2015. http://whc.unesco.org/en/decisions/6304 
and an elevation of the groundwater table, both of which may harm the heritage site. Use stone and rock stabilization methods.

Action 2: Avoid construction projects that generate excessive vibration in close proximity to the Luxor and Karnak sites, as well as the Processional Avenue.

Action 3: Develop and involve small and medium-sized enterprises and create opportunities for small businesses.

Action 4: Creating a monitoring unit to observe the performance of the development projects.

Strategy 3: Develop architectural design guidelines for construction in the area around the core and buffer zones of the World Heritage Site on the east bank

Action 1: Control building height, density, and style in order that they respect the character of the site.

Action 2: Use local building materials whenever possible.

Strategy 4: Promote continuous and frequent dialogue between project departments and the different ministries responsible for the site

Action 1: Establish a committee that includes the necessary representatives and set up regular meetings for discussions.

\section{Strategy 5: Control traffic}

Action 1: Control traffic by limiting heavy vehicles, including tourist buses, inside the buffer zone as much as possible.

\section{Strategy 6: Improve the quality of local communities}

Action 1: Provide job opportunities for local communities in new investment projects.

Action 2: Provide similar or improved new housing for local populations, giving priority to displaced families. 


\section{Conclusion}

Like many other countries in Africa, Egypt is experiencing rapid industrialization and increased population density, resulting in unprecedented pressure on both natural and cultural resources. Any development in proximity to a World Heritage Site has the potential to negatively affect the site. No heritage impact assessment tools are applied in the current management system in Egypt. This paper argues that the ICOMOS heritage impact assessment tool could be an indispensable tool for the preservation, protection, and promotion of cultural diversity and community value systems in order to enhance sustainable development. It is therefore important to find suitable mechanisms to implement HIA in Egypt. As suggested in this paper, a critical study of the development of heritage site management is an effective means to better understand the elements and key attributes of a heritage site, and to help improve sustainable management systems.

\section{Bibliography}

ABT ASSOCIATES INC. \& BARAKA TRADING. Final Report for the First Phase (in Arabic). 1998.

BEDNARSKI, Andrew. Holding Egypt: Tracing the Reception of the 'Description de l 'Égypte' in Nineteenth-century. Great Britain: Golden House Publications, 2005.

BORAIK, Mansour. Sphinx Avenue Excavations. First Report. Cahiers de Karnak 13. Cairo: Centre franco-égyptien d'étude des temples de Karnak, 2010.

BUDGE, E. A. Wallis. Cook's Handbook for Egypt and the Egyptian Sudan, with Chapters on Egyptian Archaeology. London: Thos. Cook \& Son, Ludgate, Kent \& Co. LTD., 1925. 
CENTRAL AGENCY FOR PUBLIC MOBILIZATION AND STATISTICS. Manual of Unified Statistics (Egypt). Luxor: Information Center, 2010.

EDWARDS, Amelia. A Thousand Miles up the Nile. New York: A. L. Burt, Publisher, 1876.

FERRI, Antonio. Il Fotografo dei Faraoni-Antonio Beato in Egitto 1860-1900. Bologna: Pendrgon, 2008.

FLEMING, Arlene, \& JESUS Julio. Cultural Heritage; Official Documents, Guidelines and Reports. Editor: Frank Vanclay, 2014. https://www.iaia.org/uploads/pdf/KeyCitations_CulturalHeritage.pdf (accessed on 25.10.2017).

GENERAL ORGANIZATION FOR PHYSICAL PLANNING, Mukhatat Altanmya Alshamela Lemohafazet Al'Uksur. Unpublished presentation, last modified March 03, 2005.

GOUD, M. Akhbar el-youm Newsletter (Egypt). Luxor. Another Shape, issue 05.11.2008.

HUMPHREYS, Andrew. Grand Hotels of Egypt in the Golden Age of Travel. Cairo, New York: The American University in Cairo, 2011 http://whc.unesco.org/en/decisions/6304 (accessed on 11.11.2016).

ICOMOS. Guidance on Heritage Impact Assessments for Cultural Heritage Properties- A publication of the International Council on Monuments and Sites. Paris: ICOMOS, 2011. http://www.icomos.org/world_heritage/HIA_20110201.pdf (accessed on 01.11.2016).

Luxor Governorate, Information Centre. Population and Area. Luxor Governorate, Luxor: 2017.

MILLET, M. \& MASSON, A. Karnak: Settlements. In Willeke Wendrich (ed.), UCLA Encyclopedia of Egyptology. Los Angeles: 2011.

PARTAL, Adriana, DUNPHY Kim. Cultural impact assessment: a systematic literature review of current methods and practice around 
the world. Impact Assessment and Project Appraisal, n. 34(1), p. 113, 2016.

SAAD, Rehab. Travel in the good old days. Cairo: Al-Ahram Weekly, Issue n. 463, 2000.

SAGNIA, Burama K. Framework for Cultural Impact Assessment. Dakar: International Network for Cultural Diversity (INCD), 2004.

Science Magazine. Excavation of the Temple of Luxor, N. ns-6, (142S), pp. 370-371, 1885. http://science.sciencemag.org/content/ns6/142s/370.2 (accessed on 12.11.2016).

SULlIVAN, Elaine A. Digital Karnak- Introduction to the Temple of Karnak. Los Angeles: 2008. http://dlib.etc.ucla.edu/projects/Karnak (accessed on 12.11.2016).

THE CRITERIA FOR SELECTION, World Heritage Center, UNESCO, 1992-2017. http://whc.unesco.org/en/criteria/ (accessed on 15.11.2016).

THE ORIENTAL INSTITUTE. Lost Egypt Photographic Catalog: The Mosque of Abu'l Haggag at Luxor Temple, 2014. https://oi.uchicago.edu/research/publications/le/mosque-abul-haggagluxor-temple (accessed on 30.08.2017).

UNESCO WORLD HERITAGE CENTRE. The Criteria for Selection. http://whc.unesco.org/en/criteria (accessed on 29.11.2017).

WAZARAT AL'ISKAN WALMUJTAMA'ĀT AL'UMRANIYA. Almukhatat Al'Istratigi Al'ām Waltafsili Limadinat Al'Uksur. WAZARAT AL'ISKAN WALMUJTAMA'ĀT AL'UMRANIYA, Cairo: 2015.

WHITCOMB, Donald and Janet Johnson. The Chicago Medieval Luxor Project, The Oriental Institute,1985-86. Edited by Janet H. Johnson. Annual Report 31. 31-34.The Oriental Institute, the University of Chicago: 1986.

WICKETT, Elizabeth. Archaeological Memory, the Leitmotifs of Ancient Egyptian Festival Tradition, and Cultural Legacy in the Festival Tradition of Luxor: the mulid of Sidi Abu'l Hajjaj al-Uqsori 
and the Ancient Egyptian "Feast of Opet". Journal of the American Research Center in Egypt. The American Research Center in Egypt, n. 45, p. 403-426, 2009.

WORLD HERITAGE COMMITTEE. State of conservation of properties inscribed on the World Heritage List. WHC15/39.COM/7B. Paris: UNESCO, 2015. http://whc.unesco.org/archive/2015/whc15-39com-7B-en.pdf (accessed on 15.11.2016).

WORLD HERITAGE CONVENTION \& UNESCO. Ancient Thebes with its Necropolis. http://whc.unesco.org/en/list/87 (accessed on 15.11.2016).

YOUSRY, Ahmed M. Comprehensive Development for the City of Luxor- UNDP Project: EGY/96/002- Evaluation Mission Report. 2004. https://erc.undp.org/evaluation/documents/download/442 (accessed on 15.11.2016).

RECEBIDO EM: 01/10/2017 APROVADO EM: 10/12/2017 